\title{
Acclimatization of manihot esculenta crantz seedlings inoculated in vitro with plant growth- promoting bacteria
}

\begin{abstract}
Micro propagation offers important advantages for the vegetative propagation of species such as cassava because it allows the elimination of pathogens in infested areas, rejuvenates the planting material, regains vigor and productivity and offers a large number of seedlings within a short period. The objective of this study was to evaluate the effect of the in vitro inoculation of cassava seedlings with plant growthpromoting bacteria (PGPBs) during the acclimatization phase. The experiment was conducted under greenhouse conditions, and the studied cultivars were "BRA Pretinha III" and "BRS Poti Branca". The PGPBs were Azospirillum amazonense (BR 11140), Herbaspirillum seropedicae (BR 11175), Paenibacillus brasiliensis (24), Paenibacillus graminis (MC 0421), Paenibacillus durus (V 2232), Gluconacetobacter diazotrophicus (BR 11284), and Streptomyces $s p$ (S 30). Electron microscopy analyses revealed satisfactory colonization of the roots, with the exception of plants that were inoculated with bacteria of the genus Paenibacillus, which exhibited a low level of colonization. Although the strains used were not homologous, the plant height, stem diameter, dry mass of shoots, dry mass of roots and accumulated nitrogen were optimized, and these features can provide greater tolerance to abiotic stresses that are promoted by the transfer of the plant from an in vitro to an ex vitro environment. The cultivar "BRS Poti Branca" showed a greater interaction with the strain Glucanoacetobacter diazotrophicus. The cultivar "BRA Pretinha III" showed a greater interaction with the strains G. diazotrophicus, Streptomyces sp., H, seropedicae and Paenibacillus brasiliensis. The PGPBs provided better performance in the cultivar "BRA Pretinha III" in relation to the cultivar "BRS Poti Branca".
\end{abstract}

Keywords: micropropagation, PGPB, colonization, cultivar, cassava, inoculation

\author{
Volume 7 Issue 5 - 2017
}

\author{
Esmeralda Aparecida Porto Lopes,' Fábio \\ André Brayner, ${ }^{2}$ Luiz Carlos Alves, ${ }^{2}$ Jadson \\ Emanuel Lopes Antunes,' José de Paula \\ Oliveira, ${ }^{3}$ Antônio Dias Santiago, ${ }^{4}$ Marcia do \\ Vale Barreto Figueiredo ${ }^{5}$ \\ 'Soil Science Graduate Program, Brazil/Estadual University of \\ Alagoas (UNEAL)/Brazil \\ ${ }^{2}$ Fundação Oswaldo Cruz, Brazil \\ ${ }^{3}$ Agronomical Institute of Pernambuco, Brazil \\ ${ }^{4}$ Embrapa Tabuleiro Costeiro, Brazil \\ ${ }^{5}$ Agronomical Institute of Pernambuco (IPA), Brazil
}

\begin{abstract}
Correspondence: Marcia do Vale Barreto Figueiredo, Soil Biology Laboratory, Agronomical Institute of Pernambuco (IPA- SEAGRI), Professor permanent member in the graduate program in Soil Science PPGCS- UFRPE. Recife-PE, Brazil.Av. Ga San Martin, I37I, Bongi - CEP 5076 I-000 - Recife - PE, Tel +55 8I 31847343,Email mbarreto@elogica.com.br
\end{abstract}

Received: March 08, 2017 | Published: September 22, 2017

\section{Introduction}

Cassava (Manihot esculenta Crantz) is one of the most exploited crops in agriculture worldwide, occupying approximately 20 million hectares with a production of approximately 276 million tons of tuberous roots that are shared almost entirely by the African $(57 \%)$, Asian (31\%) and American (10\%) continents FAO, ${ }^{1}$ The reason for its widespread diffusion is due mainly to the ability of cassava to adapt to different climate and soil conditions, as well as its ease of cultivation and, mainly, its higher biological efficiency, which allows for the conversion of greater amounts of solar energy into carbohydrates per unit area $\left(250.10^{3} \mathrm{cal} / \mathrm{ha} /\right.$ day $)$ compared with other crops such as corn, rice, sorghum and wheat Okigbo. ${ }^{2}$ Thus, cassava is one of the basic foods used by millions of people, not only as an important reserve against hunger for poor people but also for the creation of jobs and income Olukunle ${ }^{3}$ Nonetheless, although it is recognized in the global socio-economic scenario, its average yield $(13 \mathrm{t} / \mathrm{ha})$ is below its productive potential, which that, ideally can reach $80 \mathrm{t} / \mathrm{ha} /$ year of roots El-Sharkawy. ${ }^{4}$ Among the various factors attributed to this poor performance, the physiological aging caused by the repeated propagation of the maniva seed has contributed to a decrease in the sprouting and vigor of the plant. In addition, the long cycle of cassava increases its susceptibility to many pests and diseases that can be transmitted from one culture cycle to another Iglesias et al., 5 contributing to a significant reduction in yield Mattos et al. ${ }^{6}$

The micropropagation technique offers advantages for the vegetative propagation of species such as cassava because, in addition to the ability of this technique to promote recovery, it enables, in a short time, the development of a large number of seedlings that are identical to the mother plant and free of pests and diseases throughout the year Pasqual et al. ${ }^{7}$ However, micro propagated seedlings have demonstrated poor performance when transferred from in vitro to ex vitro conditions Mello et al., ${ }^{8}$ hindering the use of this biotechnology in commercial agricultural practices Kapoor et al. ${ }^{9}$ This phenomenon is due to autotrophic cultivation, which eliminates both phytopathogenic microorganisms and microorganisms that may be advantageous for the growth and development of plants Panicker et al., ${ }^{10}$ as some of these microorganisms produce or induce the production of primary and secondary metabolites that can confer several benefits to the host plants, such as increased tolerance to abiotic stresses Bogino et al. ${ }^{11}$

To circumvent this challenge, a technology developed in recent years that has been positively used to improve many growth and productivity parameters in plants is the inoculation of microorganisms that are capable of colonizing the root environment, competing with the soil biota and providing benefits that promote plant growth. Among these microorganisms, plant growth-promoting bacteria (PGPBs) can be isolated from different environments Figueiredo et al. ${ }^{12}$ Chanway et al. ${ }^{13}$ and have the capacity to colonize the surface of roots, the rhizosphere and the phyllosphere, as well as internal plant tissues, modulating the metabolism and stimulating plant growth through nitrogen fixation Hoffman et al., ${ }^{14}$ the solubilization of inorganic phosphates and zinc Richardson et al., ${ }^{15}$ Sarathambal et al., ${ }^{16}$ phosphorus uptake, sulfur oxidation El-Tarabily et al., ${ }^{17}$ and 
siderophore synthesis. They also participate in the iron chelating of biopesticides agents, thus reducing the intensity of the inoculum or the activities responsible for phyto-disease Malfanova et al. ${ }^{18}$ These activities occur mainly through the synthesis of growth regulators Kurepin et al. ${ }^{19}$ that promote alterations in the root system, including increases in the number and length of lateral roots Bashan et al. ${ }^{20}$ Cassán et al., ${ }^{21}$ thus contributing to increases in plant resistance to water and nutritional stress Figueiredo et al.;22 Carvalhais et al. ${ }^{23}$ Based on the knowledge that seedlings, when established ex vitro, have reduced survival rates and marginal growth and that the use of microorganisms is a relatively unexamined application in cassava seedlings, we hypothesized that the inoculation of cassava with plant growth-promoting bacteria (PGPBs) would optimize the growth, vigor and sanity of the plant, with increases in survival rates. This hypothesis was tested in micropropagation plants of cassava during the acclimatization stage. Different PGPBs inoculated alone and various biological and physiological parameters were evaluated in this study.

\section{Materials and methods}

\section{Multiplication and preparation of the inoculants}

The PGPB strains used in this study are listed in Table 1. To obtain inoculants, the samples were grown in Erlenmeyer flasks containing specific culture media. Strains BR 11140, BR 11175 and BR 11284 were grown in DYGS (Dextrose Yeast Glucose Sucrose) culture medium for 48hours, whereas strains MC 04.21, 24, and V 22.32 were grown in TSB (tryptic soy broth) culture medium for 24 or 48 hours according to the bacterial strain. Strain S 30 was grown in AYA (arginine, yeast and agar) culture for 120 hours. (All strains were subjected to a constant agitation of $200 \mathrm{rpm}$ at $29^{\circ} \mathrm{C}$ ).

Table I Origin and mechanisms of growth promoting of the plant growth promoting bacteria (PGPB) inoculated in Manihot esculenta Crantz

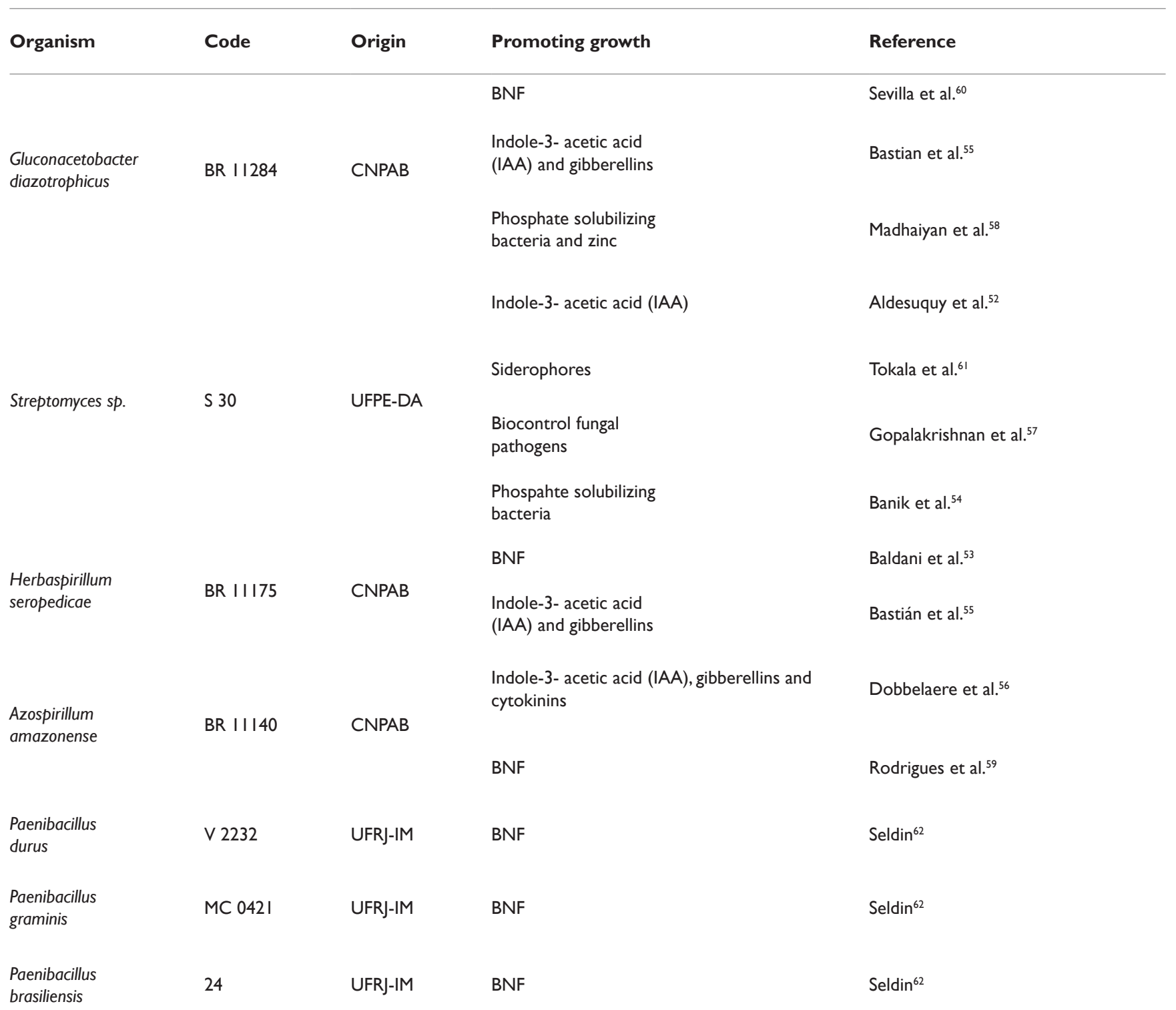




\section{Selection and disinfection of manivas}

The manivas of the cultivars "BRS Poti Branca" and "BRA Pretinha III" were disinfected according to Araújo et al. ${ }^{24}$ The experiment was conducted in a greenhouse, and the manivas were planted in trays for germination that contained a mixture of substrate + washed sand (1:1) that had been autoclaved at $120^{\circ} \mathrm{C}, 101 \mathrm{kPa}$, for 1 hour; the $\mathrm{pH}$ was adjusted to 6.0 and maintained at field capacity until budding.

\section{Isolation of sprouts, establishment of shoot tips and} propagation of cassava plants

The sprouts were harvested 15days after planting (DAP) and disinfected in a laminar flow hood according to the method described by Souza et al. ${ }^{25}$ The apices were isolated and established in MS Murashige et al., ${ }^{26}$ medium supplemented with thiamine$\mathrm{HCl}(1 \mathrm{mg} / \mathrm{L})$, inositol $(100 \mathrm{mg} / \mathrm{L})$, naphthalene acetic acid (NAA) $(0.02 \mathrm{mg} / \mathrm{L})$, benzylaminopurine (BAP) $(0.04 \mathrm{mg} / \mathrm{L})$, gibberellic acid (GA3) $(0.05 \mathrm{mg} / \mathrm{L})$, sucrose $(20 \mathrm{~g} / \mathrm{L})$ Roca et al., ${ }^{27}$ and agar $(8 \mathrm{~g} / \mathrm{L})$. Thirtydays after establishment of the apices, calluses and roots were removed and propagated according to Souza et al. ${ }^{25}$ The plants were kept maintained for 90 days in a growth chamber at $26 \pm 1^{\circ} \mathrm{C}$ supplied with artificial light (1948 lux) under a photoperiod of 16hours.

\section{Inoculation of PGPBs}

When the seedlings presented an abundance of roots and leaves in vitro and reached a height of $10 \mathrm{~cm}$, they were inoculated following the methodology of Reis. ${ }^{28}$ Each plant received a 2-mL suspension of bacteria grown in a specific medium with a bacterial density of $\sim 10^{8}$ cells $\mathrm{mL}^{-1}$. In the control treatment $(\mathrm{CT})$, the bacterial suspension was not increased, and none of the plants received nitrogen fertilizer. The plants were then maintained in a growth chamber for 10days at $26 \pm 1{ }^{\circ} \mathrm{C}$ under artificial lighting (1948lux) with a photoperiod of 16hours. To evaluate the colonization ability of the bacteria, roots fragments ( $\sim 1-2 \mathrm{~cm}$ in length) of the plants were collected 10days after the inoculation, washed in $0.1 \mathrm{M}$ sodium cacodylate buffer, $\mathrm{pH} 7.4$, and fixed in $0.1 \mathrm{M}$ cacodylate buffer containing $2.5 \%$ glutaraldehyde (Sigma Aldrich). The post-fixation procedure was performed with $1 \%$ osmium tetroxide (Sigma Aldrich). The root fragments were then rinsed in $0.1 \mathrm{M}$ cacodylate buffer, dehydrated with ethanol and, after the material was dry, covered with a thin layer of gold for visualization of the bacterial isolates by scanning electron microscopy (SEM).

\section{Acclimatization}

To evaluate the effect of the PGPB inoculation on cassava seedlings during the acclimatization stage, an experiment was conducted in a greenhouse at the Headquarters of the Agronomic Institute of Pernambuco - IPA. The soil used was classified as duric orthic Spodosol EMBRAPA ${ }^{29}$ and has the following characteristics in the layer $(0-20 \mathrm{~cm}) ; 5.50 \mathrm{pH}\left(\mathrm{H}_{2} \mathrm{O}\right) ; 16 \mathrm{mg} \mathrm{dm}^{-3} \mathrm{P} ; 0.06 \mathrm{cmol} \mathrm{dm}^{-3}$ $\mathrm{K} ; 1.30 \mathrm{cmol} \mathrm{dm}^{-3} \mathrm{Ca}^{2+} ; 0.70 \mathrm{cmol}_{\mathrm{c}} \mathrm{dm}^{-3} \mathrm{Mg}^{+2}, 0.15 \mathrm{dm}^{-3} \mathrm{cmol}^{\mathrm{c}} \mathrm{Al}$ and $4.63 \mathrm{dm}^{-3} \mathrm{cmol}_{\mathrm{c}} \mathrm{H}$. The substrate had a $\mathrm{pH}$ in water of $5.0+/-0.5$. The temperature and humidity ranged between $30-32^{\circ} \mathrm{C}$ and $50-55 \%$ during the day, respectively. Seedlings derived from the cultivation of meristems 10days after inoculation of the PGPB suspension were planted in disposable $0.5-\mathrm{L}$ plastic cups with a depth of $12 \mathrm{~cm}$, filled with a mixture of soil + ground substrate at a ratio of $1: 1$, sterilized at $120^{\circ} \mathrm{C}, 101 \mathrm{kPa}$, for 1 hour and adjusted to a $\mathrm{pH}$ of 6.0 . To maintain the moisture levels, the plants were covered with plastic cups Souza et $a .^{25}$ At 20 DAP, the cups were removed, and the plants were nourished with Hoagland et al. ${ }^{30}$ solution that had been modified according to Silveira et al..$^{31}$ The plants were harvested at 52 days after the in vitro inoculation, and the following variables were evaluated: bacterial colonization, survival percentage, plant height, root length, stem diameter, dry mass of shoot (DMS), dry mass of root (DMR), accumulated nitrogen in the dry mass of shoots $\left(\mathrm{Na}_{\mathrm{c}} \mathrm{DMS}\right)$ and the DMS/DMR relationship.

\section{Statistical analysis}

The experimental design was randomized blocks in a factorial design (8x2) consisting of seven strains of bacteria +1 control treatment (no bacteria) (CT) and two cassava cultivars with three replications because the experimental unit consisted of three replicates. Each studied variable was subjected to analysis of variance (ANOVA) using the statistical program SISVAR 5.1 Build 72 with a significance level of 5\% according to the $\mathrm{F}$ test and the comparison of averages by the Tukey test $(\mathrm{p}<0.05)$.

\section{Results and discussion}

\section{Cassava micro propagated plant survival in response to bacterial colonization}

The application of scanning electron microscopy (SEM) allowed the confirmation of the effectiveness of the bacterial colonization process in cassava seedlings in vitro. All of the inoculated strains had the ability to colonize the roots of the two cassava cultivars (Figures 1) (Figure 2), which is essential for the long-term association because, according to Bashan et al..$^{32}$ the metabolites excreted by PGPBs that are not associated with root epidermal cells diffuse into the rhizosphere and are consumed by microorganisms prior to benefiting the host. The PGPBs that demonstrated the best colonization of the roots when viewed at a high resolution were Gluconacetobacter diazotrophicus (BR 11284), Azospirillum amazonense (BR11140), Herbaspirillum seropedicae (BR 11175) and Streptomyces sp. (S 30). In contrast, the roots inoculated with bacteria of the genus Paenibacillus (24, V 22.32 and $\mathrm{MC}$ 04.21) did not show this feature, displaying a low rate of colonization in relation to the other PGPBs (Figures 1A-1H \& 2A$2 \mathrm{H})$.

\section{Inoculation of PGPBs and development of cassava seedlings}

The bacterial strains differed significantly by the Tukey test $(p<0.05)$ in terms of their ability to promote a higher percentage of survival (SR) in cassava seedlings after the acclimatization period. In cv. "BRS Poti Branca" and "BRA Pretinha III", the control treatment (CT) favored a survival rate of $100 \%$ and $75 \%$, respectively. Furthermore, the CT for these strains did not differ from those obtained for , G. diazotrophicus, H. seropedicae and Streptomyces sp., but it did differ from the results obtained for Paenibacillus graminis and $P$. durus, which promoted a mortality rate of $92 \%$ and $83 \%$ in "BRS Poti Branca" and of $100 \%$ in "BRA Pretinha III" (Table 2). It is common for seedlings transferred to ex vitro conditions to present a high mortality rate due to non-functional stomata, an undeveloped root system and small thick leaves with little or no cuticular wax Kapooret al. ${ }^{9}$ It is also noteworthy that despite the low survival rate promoted by the genus Paenibacillus, the P. durus strain interacted more with the cv. "BRS Poti Branca" (17\%) than with the cv. "BRA Pretinha III" $(0 \%)$ at a $5 \%$ probability by the Tukey test. The observation that the cassava seedlings of both cultivars did not display an increased resistance to the supposed biotic and abiotic stresses relative to the acclimatization period following their inoculation with PGPBs can be explained by the paucity of plant-bacteria interactions because this process is complex and can be influenced by various biotic and abiotic factors, such as the inoculum density, host species, cultivar, temperature Pillay et al. ${ }^{33}$ seasonal variations, types of plant tissue Kuklinsky-Sobral et al., ${ }^{34}$ soil type Fromim et al., ${ }^{35}$ and interactions 
with other microorganisms Figueiredo et al. ${ }^{36}$ The variable root length (RL) at 42days after planting Table 2 in response to PGPB inoculation did not differ between the seedlings of the cultivars by the Tukey test $(p<0.05)$. Work conducted by Mathur et al., ${ }^{37}$ showed that micro propagated plants often have small root systems. Regarding the stem diameter $(\mathrm{SD})$, there were significant differences $(\mathrm{p}<0.05)$ in the effects of the PGPBs in each cultivar. In cv. "BRA Pretinha III", all of the PGPBs promoted a significant increase in the stem diameter thickness compared with the absolute control (AC). However, in cv. "BRS Poti Branca", strains P. durus, P. graminis, P. brasiliensis and $A$. amazonense induced a significant decrease compared with the control. Thicker stems were observed when the seedlings of the two cultivars were inoculated with strain $G$. diazotrophicus (Table 2), demonstrating increments of $53 \%$ and $25 \%$ for cv. "BRA Pretinha III" and "BRS Poti Branca", respectively. Thus, it is anticipated that seedlings with thicker diameters will give rise to plants with a more vigorous root system, contributing to an increase in water absorption and favoring greater survival in the field and, consequently, increased production Santos et al..$^{38}$

With the exception of strain $P$. graminis, all of the PGPBs significantly stimulated $(\mathrm{p}<0.05)$ the seedling height $(\mathrm{SH})$ in relation to the CT in cultivar "BRA Pretinha III". However, in the cultivar "BRS Poti Branca", $P$. graminis and $P$. brasiliensis induced a significant decrease in SH when compared with CT. Strains H. seropedicae and G. diazotrophicus promoted an increase of $67 \%$ and $19.7 \%$ in the $\mathrm{SH}$ of "BRA Pretinha III" and "BRS Poti Branca", respectively, when compared with CT (Table 2). Although the beneficial effects of the inoculation of plants and seeds with bacteria include improvements in nutrition and increasing productivity Naik et al., ${ }^{39}$ deleterious effects have also been observed by Probanza et al., ${ }^{40}$ who reported a reduction in the length of shoots and roots and in the biomass of pine plants (Pinus taeda L.) following inoculation with B. subtillus (BS1 and BS2). These results support the notion that the ability of PGPBs to produce metabolites is not necessarily a prerequisite for an increase in the growth and yield of the plants because the beneficial effect depends on its concentration Saharan et al. ${ }^{41}$

Regarding the interactions between plants and bacteria, the cultivars showed significant differences in plant height variability at a $5 \%$ probability by the Tukey test following inoculation with the Paenibacillus genus. These results demonstrated that inoculation with $P$. graminis and $P$. durus in the cultivar "BRS Poti Branca" performed better in $\mathrm{SH}$, whereas $P$. brasiliensis displayed a greater interaction with the cultivar "BRA Pretinha III" (Table 2). This difference may be related to the different photo assimilates produced by each cultivar, which provide specific carbon sources that may favor the attraction, retention or inhibition of a microorganism in the rhizospheric region Valé et $\mathrm{al}^{42}$ The results presented for the accumulation of the dry mass of the shoot (DMS) (Table 3) indicate significant differences $(p<0.05)$ in the effects of PGPBs in each cultivar. For the cultivar "BRA Pretinha III", strains Streptomyces sp, H. seropedicae and G. diazotrophicus promoted a significant increase in the DMS when compared with the absolute control (AC), and P. graminis did not differ from AC. However, G. diazotrophicus promoted an increase in DMS in cultivar "BRS Poti Branca" in relation to CT, while P. durus, $P$. graminis and $P$. brasiliensis did not differ from CT. The strains Streptomyces sp and G. diazotrophicus promoted increments of $200 \%$ and $131 \%$ in DMS accumulation in the cultivars "BRA Pretinha III" and "BRS Poti Branca", respectively (Table 3).

The plant-bacteria interactions (Table 3) exhibited significant differences $(\mathrm{p}<0.05)$ in the cassava cultivars in relation to the PGPBs following inoculation with Paenibacillus graminis, P. brasiliensis and G. diazotrophicus. P. graminis and G. diazotrophicus strains have been shown to provide greater benefits in DMS (46\% and 32\%) when inoculated in cv. "BRA Poti Branca" in relation to "BRA Pretinha III", while the reverse has been observed for the strain P. brasiliensis, which provided an increase of $44 \%$ compared with the DMS of "BRS Poti Branca" (Table 3). These results corroborate those reported by Araújo, ${ }^{43}$ who found that PGPBs influence plants to produce a greater shoot biomass, and this response varies according to the plant species and/or strains used.

With regard to the dry mass of the root (DMR), the results showed a significant difference $(\mathrm{p}<0.05)$ in terms of the effects of PGPBs in each cultivar (Table 3 ). The $P$. brasiliensis strain promoted an increase in the DMR when inoculated into seedlings of the cultivar "BRA Pretinha III" compared with CT, while P. graminis did not differ significantly from CT. However, for the cultivar "Poti Branca", a significant increase was identified $(\mathrm{p}<0.05)$ in the production of DMR following inoculation with $G$. diazotrophicus; however, no significant differences were detected between $P$. durus and CT. The strains $P$. brasiliensis and $G$. diazotrophicus promoted an increase of $400 \%$ and $200 \%$ in DMR accumulation in the cultivars "BRA Pretinha III" and "BRA Poti Branca", respectively, in relation to CT (Table 3). No significant differences were observed $(\mathrm{p}<0.05 \%)$ among the PGPBs and the cultivar "Poti Branca" regarding the relationship of the dry mass of the shoot/dry mass of the root (DMS/DMR), suggesting that the strains did not influence this relationship at this stage of plant development. However, the seedlings of the cultivar "BRA Pretinha III" inoculated with the strain $P$. graminis ( $4.93 \mathrm{~g} / \mathrm{plant})$ displayed no significant differences by the Tukey test $(\mathrm{p}<0.05)$ compared with the other bacteria, excluding the seedlings that were inoculated with Streptomyces sp. (2.47 g/plant) (Table 3).

In this study, a higher accumulation of DMS was observed in two cassava cultivars compared with those observed in the DMR. According to Alves, ${ }^{44}$ the period of maximum rates of total dry mass accumulation depends on the genotype and growth conditions used for the plant. During the growth of cassava, the carbohydrates produced by photosynthesis must be distributed to ensure the good development of both shoots and roots; notwithstanding, after 75 DAP, the photo assimilates begin to be translocated to the roots. This statement corroborates the present results given that the seedlings demonstrated a reduced accumulation of DMR, resulting in higher values for DMS/DMR. The positive effects on the accumulation of DMS and DMR for cassava may be associated with the ability of strains Gluconacetobacter diazotrophicus, Herbaspirillum seropedicae, Paenibacillus brasiliensis and Streptomyces $s p$ to fixate atmospheric nitrogen (BNF) and synthesize growth hormones or even a synergistic effect of these two factors Canuto et al. ${ }^{45}$ Among phytohormones, Indole acetic acid (IAA) causes changes in the morphology of roots, influencing the uptake of nutrients and water and hence promoting plant growth Aguilar-Piedras et al. ${ }^{46}$ Canuto et al., ${ }^{45}$ showed a significant increase in the accumulation of the dry mass of the roots of micro propagated sugarcane plants following inoculation with $H$. seropedicae and $G$. diazotrophicus. Meguro et al. ${ }^{47}$ observed a rapid emergence and elongation of roots in micro propagated Rhododendron plants that were inoculated with Streptomyces $s p$. Mello et al. ${ }^{8}$ observed an increase in DMS and DMR in micro propagated pineapple seedlings that were inoculated with Bacillus $s p$. Despite the well-described ability of some strains of Paenibacillus to promote plant growth Rodrigues et al. ${ }^{48}$ in the present study, inoculation of the strains $P$. durus, $P$. graminis and $P$. brasiliensis into the cultivar "Poti Branca" did not promote an increase in these variables. Thus, a reduced effect indicative of the plant-bacteria interactions is suggested, compromising the mobilization of nutrients and, consequently, the development of the plant. 


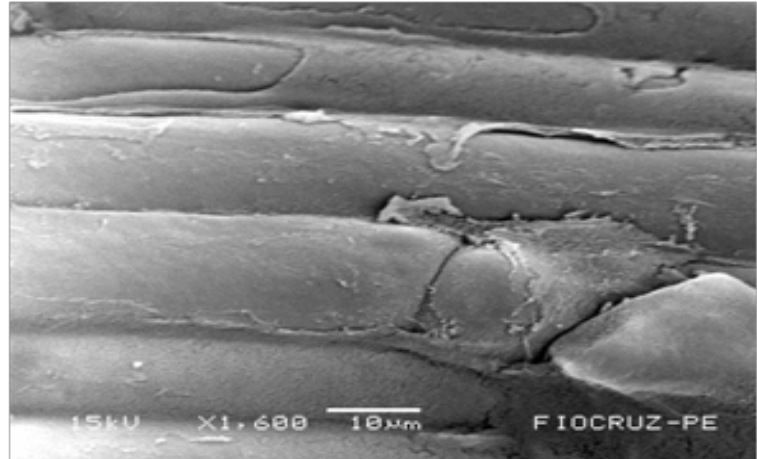

Figure IA Control treatment (CT).

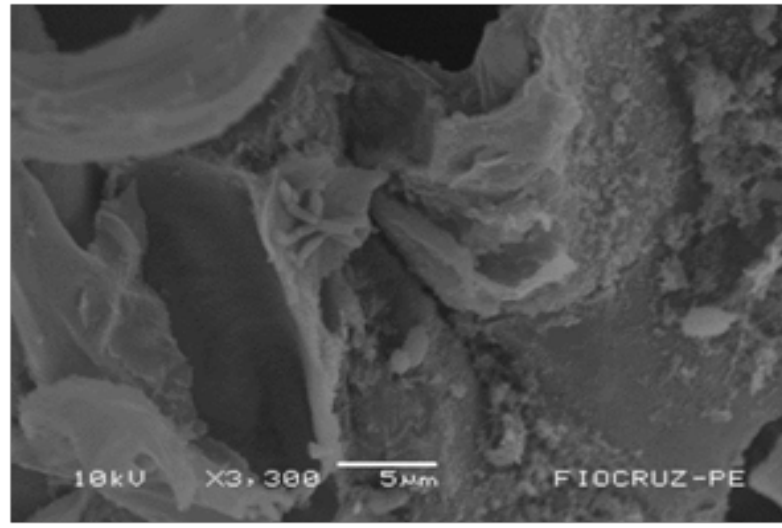

Figure IC Paenibacillus durus (V 2232).



Figure IE Azospirillum amazonense (BR I I I40).



Figure IG Gluconacetobacter diazotrophicus (BR I | 284).

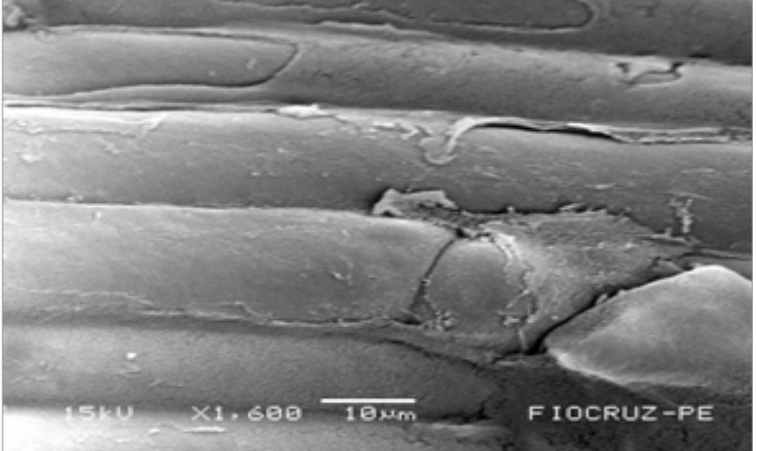

Figure IB Paenibacillus brasiliensis (24).

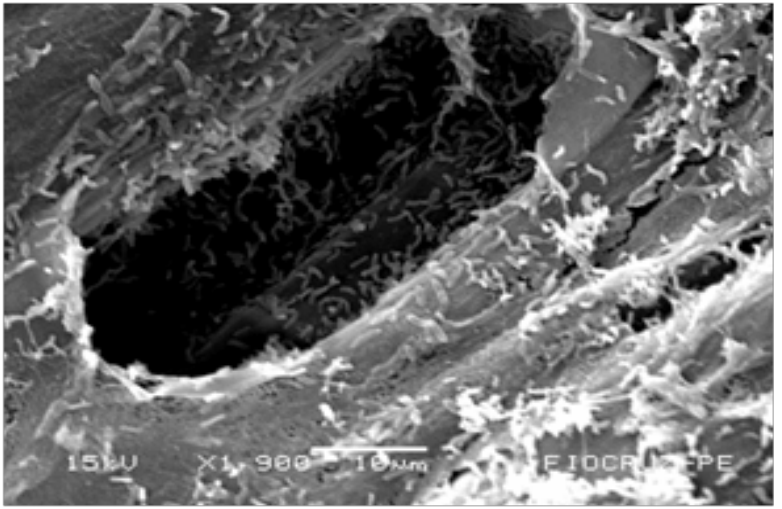

Figure ID Paenibacillus graminis (MC 042I)

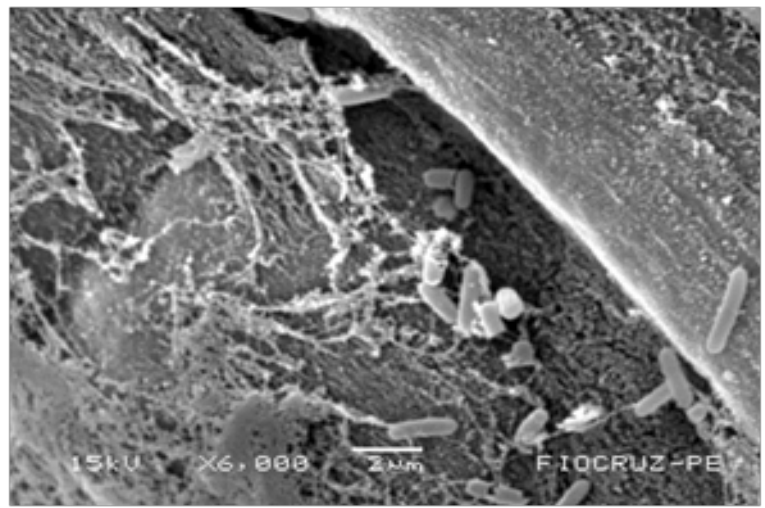

Figure IF Herbaspirillum seropedicae (BR I I I75).



Figure IH Streptomyces sp. (S 30) obtained by scanning electron microscopy.

Figures I A-I H Images of the root fragments of cassava seedlings of "BRA Pretinha III" cultivar inoculated. 




Figure 2A Control treatment (CT).



Figure 2C Paenibacillus durus (V 2232).

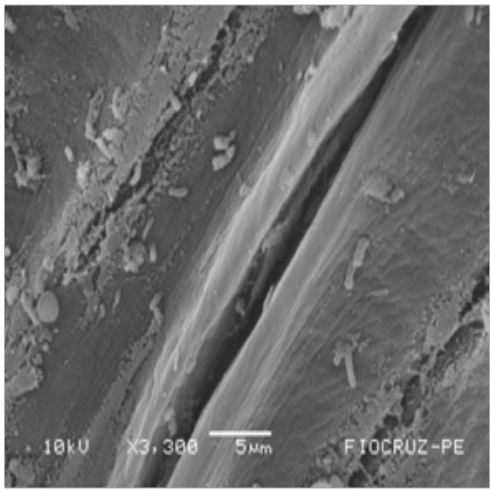

Figure 2E Azospirillum amazonense (BR II |40).

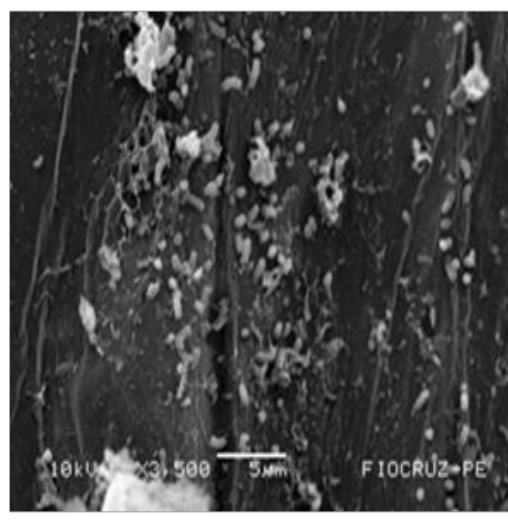

Figure 2G Gluconacetobacter diazotrophicus (BR I I 284).



Figure 2B Paenibacillus brasiliensis (24).

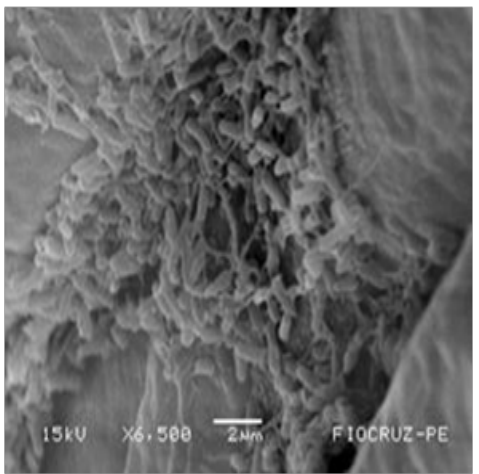

Figure 2D Paenibacillus graminis (MC 042I)



Figure 2F Herbaspirillum seropedicae (BR III 75).

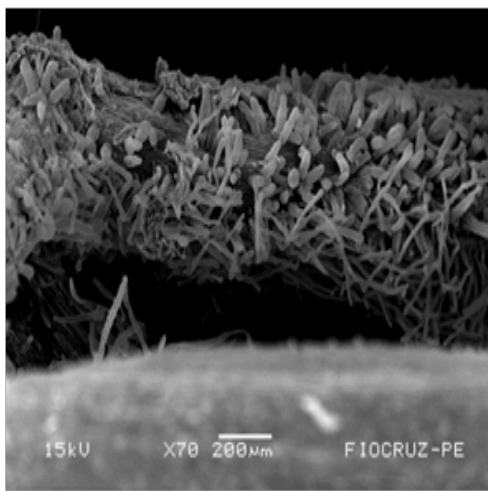

Figure $\mathbf{2 H}$ Streptomyces sp. (S 30) obtained by scanning electron microscopy.

Figures 2A-2G Images of the root fragments of cassava seedlings of "BRA Poti Branca" cultivar inoculated.

Citation: Lopes EAP, Brayner FA, Alves LC, et al.Acclimatization of manihot esculenta crantz seedlings inoculated in vitro with plant growth-promoting bacteria. Adv Plants Agric Res. 2017;7(5):377-386. DOI: 10.15406/apar.2017.07.00270 
Table 3 shows the results for the accumulation of nitrogen in the dry mass of the shoot (Nac DMS), showing a significant difference by the Tukey test $(\mathrm{p}<0.05)$ in the effects of PGPBs in each cultivar. The highest accumulation of Nac DMS in cv. "BRA Pretinha III" was induced by strains $H$. seropedicae and $G$. diazotrophicus, with values (12.25mg N/plant) that exceeded three times the amount of accumulated nitrogen on $\mathrm{AC}(3.88 \mathrm{mgN} /$ plant). However, strain G. diazotrophicus promoted the highest values $(13.42 \mathrm{mgN} / \mathrm{plant})$ compared with CT $(6.26 \mathrm{mgN} /$ plant), while strains $P$. brasiliensis and $P$. durus showed no differences compared with CT. Regarding the interaction between PGPBs $\mathrm{x}$ the cultivars, a significant difference $(\mathrm{p}<0.05)$ was identified when cassava was inoculated with the strains P. graminis, A. amazonense and P. brasiliensis. The first two strains promoted an increase in Nac MSPA in "BRS Poti Branca", while the inoculation with $P$. brasiliensis resulted in a higher accumulation of Nac. in the cultivar "BRA Pretinha III".

The Nac contribution was $114 \%$ and $210 \%$ in the cultivars "BRS Poti Branca and "BRA Pretinha III", respectively. These same

Table 2 Survival rate (SR), stem diameter (DS), seedling height (SH) and root length (LR) of cassava plantlets (Manihot esculenta Crantz) cv. ("BRS Poti Branca" and "BRA Pretinha III") assessed for inoculation of the plant growth promoting bacteria (PGPB) strains, as previously noted, provided a greater accumulation of DMS and DMR (Table 3). Plant growth is related to the accumulation of nitrogen in the shoot, as demonstrated by the highly significant linear relationships of the weight of the dry mass of the shoot in cultivars "BRA Pretinha III" $\left(\mathrm{y}=0.0244 \mathrm{X}-0.0054 \quad\left(\mathrm{R}^{2}=0.949\right)\right)$ and "BRS Poti Branca" ( $\left.\mathrm{y}=0.0289 \mathrm{X}-0.0502\left(\mathrm{R}^{2}=0.886\right)\right)$. For the cv. "BRA Pretinha III", the greatest increase in DMS $(0.30 \mathrm{~g})$ occurred with the accumulation of Nac $(11.01 \mathrm{mgN} /$ plant), while the greatest increase in DMS $(0.37 \mathrm{~g})$ in "BRS Poti Branca" occurred with an increase in the accumulation of Nac (13.42mgN/plant). The interactions among of $\mathrm{N}(20 \%$ and $55 \%)$, respectively. According to Bashan et al. ${ }^{49}$ and Bashan et al., ${ }^{50}$ moderate increases of approximately $20 \%$ in response to inoculation with endophytic diazotrophic bacteria would be considered commercially significant in modern agriculture. Therefore, the present results are promising because knowledge regarding the effects of the inoculated strains in the greenhouse and in the field is needed to better understand plant-bacteria-soil interactions. ${ }^{51-62}$ cassava $\mathrm{x} P$. durus and $P$. graminis resulted in the lowest contributions

\begin{tabular}{|c|c|c|c|c|c|c|c|c|}
\hline \multirow{3}{*}{ Treatment } & \multicolumn{8}{|l|}{ Cultivars } \\
\hline & $\begin{array}{l}\text { Poti } \\
\text { Branca }\end{array}$ & $\begin{array}{l}\text { Pretinha } \\
\text { III }\end{array}$ & $\begin{array}{l}\text { Poti } \\
\text { Branca }\end{array}$ & $\begin{array}{l}\text { Pretinha } \\
\text { III }\end{array}$ & $\begin{array}{l}\text { Poti } \\
\text { Branca }\end{array}$ & $\begin{array}{l}\text { Pretinha } \\
\text { III }\end{array}$ & $\begin{array}{l}\text { Poti } \\
\text { Branca }\end{array}$ & $\begin{array}{l}\text { Pretinha } \\
\text { III }\end{array}$ \\
\hline & SR (\%) & & DS (mm) & & $\mathrm{SH}(\mathrm{cm})$ & & $\operatorname{LR}(\mathrm{cm})$ & \\
\hline 'G. diazotrophicus & $\begin{array}{l}83.33 \pm \\
16.67 \mathrm{abA}\end{array}$ & $\begin{array}{l}66.67 \pm \\
16.67 \mathrm{aA}\end{array}$ & $2.14 \pm 0.06 \mathrm{aA}$ & $\begin{array}{l}1.99 \pm \\
0.15 \mathrm{aA}\end{array}$ & $\begin{array}{l}13.17 \pm \\
0.30 \mathrm{aA}\end{array}$ & $\begin{array}{l}11.83 \pm \\
0.4 \mathrm{labA}\end{array}$ & $\begin{array}{l}14.50 \pm \\
0.66 \mathrm{aA}\end{array}$ & $\begin{array}{l}15.83 \pm \\
0.90 \mathrm{aA}\end{array}$ \\
\hline Streptomyces sp & $\begin{array}{l}91.67 \pm \\
8.33 \mathrm{aA}\end{array}$ & $\begin{array}{l}75.00 \pm \\
8.33 \mathrm{aA}\end{array}$ & $\begin{array}{l}1.78 \pm \\
0.15 \mathrm{abA}\end{array}$ & $\begin{array}{l}1.68 \pm \\
0.12 \mathrm{abA}\end{array}$ & $\begin{array}{l}12.33 \pm \\
0.83 \mathrm{abA}\end{array}$ & $\begin{array}{l}11.78 \pm \\
0.49 \mathrm{abA}\end{array}$ & $\begin{array}{l}14.72 \pm \\
0.69 \mathrm{aA}\end{array}$ & $\begin{array}{l}12.72 \pm \\
1.67 \mathrm{aA}\end{array}$ \\
\hline${ }^{2} \mathrm{H}$. seropedicae & $\begin{array}{l}66.67 \pm \\
8.33 \mathrm{abA}\end{array}$ & $\begin{array}{l}75.00 \pm \\
0.00 \mathrm{aA}\end{array}$ & $\begin{array}{l}1.65 \pm \\
0.1 \text { labA }\end{array}$ & $\begin{array}{l}1.79 \pm \\
0.13 \mathrm{abA}\end{array}$ & $\begin{array}{l}12.11 \pm \\
0.59 \mathrm{abA}\end{array}$ & $\begin{array}{l}12.61 \pm \\
0.70 \mathrm{aA}\end{array}$ & $\begin{array}{l}12.89 \pm \\
0.77 \mathrm{aA}\end{array}$ & $\begin{array}{l}15.11 \pm \\
0.70 \mathrm{aA}\end{array}$ \\
\hline${ }^{3} \mathrm{~A}$. amazonense & $\begin{array}{l}91.67 \pm \\
8.33 \mathrm{aA}\end{array}$ & $\begin{array}{l}75.00 \pm \\
25.00 \mathrm{aA}\end{array}$ & $\begin{array}{l}1.55 \pm \\
0.12 \mathrm{bA}\end{array}$ & $\begin{array}{l}1.55 \pm \\
0.06 \mathrm{abA}\end{array}$ & $\begin{array}{l}11.28 \pm \\
0.66 \mathrm{abA}\end{array}$ & $\begin{array}{l}11.17 \pm \\
0.49 \mathrm{abA}\end{array}$ & $\begin{array}{l}15.11 \pm \\
0.99 \mathrm{aA}\end{array}$ & $\begin{array}{l}13.78 \pm \\
0.84 \mathrm{aA}\end{array}$ \\
\hline${ }^{4}$ P. durus & $\begin{array}{l}16.67 \pm \\
8.33 c A\end{array}$ & $\begin{array}{l}0.00 \pm \\
0.00 \mathrm{bB}\end{array}$ & $\begin{array}{l}1.60 \pm \\
0.07 \mathrm{bA}\end{array}$ & $\begin{array}{l}1.49 \pm \\
0.07 \mathrm{abA}\end{array}$ & $\begin{array}{l}11.28 \pm \\
0.44 a b A\end{array}$ & $\begin{array}{l}9.44 \pm \\
0.78 \mathrm{bcB}\end{array}$ & $\begin{array}{l}14.72 \pm \\
1.07 \mathrm{aA}\end{array}$ & $\begin{array}{l}15.44 \pm \\
0.72 \mathrm{aA}\end{array}$ \\
\hline P. graminis & $\begin{array}{l}8.33 \pm \\
8.33 \mathrm{cA}\end{array}$ & $\begin{array}{l}0.00 \pm \\
0.00 \mathrm{bA}\end{array}$ & $\begin{array}{l}1.54 \pm \\
0.14 \mathrm{bA}\end{array}$ & $\begin{array}{l}1.49 \pm \\
0.11 \mathrm{abA}\end{array}$ & $\begin{array}{l}10.00 \pm \\
0.48 \mathrm{bA}\end{array}$ & $\begin{array}{l}8.17 \pm \\
0.70 c B\end{array}$ & $\begin{array}{l}16.16 \pm \\
1.74 \mathrm{aA}\end{array}$ & $\begin{array}{l}16.72 \pm \\
1.67 \mathrm{aA}\end{array}$ \\
\hline P. brasiliensis & $\begin{array}{l}33.33 \pm \\
22.04 \mathrm{bcA}\end{array}$ & $\begin{array}{l}33.33 \pm \\
8.33 \mathrm{aA}\end{array}$ & $\begin{array}{l}1.57 \pm \\
0.15 \mathrm{bA}\end{array}$ & $\begin{array}{l}1.81 \pm \\
0.11 \mathrm{abA}\end{array}$ & $\begin{array}{l}9.89 \pm \\
0.47 \mathrm{bB}\end{array}$ & $\begin{array}{l}11.83 \pm \\
0.96 \mathrm{abA}\end{array}$ & $\begin{array}{l}15.53 \pm \\
1.31 \mathrm{aA}\end{array}$ & $\begin{array}{l}14.77 \pm \\
0.87 \mathrm{aA}\end{array}$ \\
\hline $\mathrm{CT}$ & $\begin{array}{l}100.00 \pm \\
0.00 \mathrm{aA}\end{array}$ & $\begin{array}{l}75.00 \pm \\
14.43 \mathrm{aA}\end{array}$ & $\begin{array}{l}1.71 \pm \\
0.22 \mathrm{abA}\end{array}$ & $\begin{array}{l}1.30 \pm \\
0.11 \mathrm{bB}\end{array}$ & $\begin{array}{l}11.00 \pm \\
0.52 \mathrm{abA}\end{array}$ & $\begin{array}{l}7.56 \pm \\
0.60 \mathrm{cB}\end{array}$ & $\begin{array}{l}12.00 \pm \\
0.58 \mathrm{aA}\end{array}$ & $\begin{array}{l}13.11 \pm \\
1.32 \mathrm{aA}\end{array}$ \\
\hline Means & 56.77 & & 1.69 & 1.64 & 11.38 & 10.55 & 14.45 & 14.69 \\
\hline$\% \mathrm{CV}$ & 23.96 & & 21.54 & & 16 & & 21.28 & \\
\hline
\end{tabular}

Means followed by the same lowercase letter among treatments within the same column, and capital letters among varieties within the same line for each parameter do not differ by Tukey test ( $p<0.05)$. ' (Gluconacetobacter-BR II 284$) ;{ }^{2}$ (Herbaspirillum-BR II I I75); ${ }^{3}$ (Azospirillum-BR III I 40); ${ }^{4}$ (Paenibacillus: durus-V 2232, graminis-MC 042I, brasiliensis - 24); Str eptomyces S 30 and CT (control treatment). For statistical analysis the data on SR were transformed into root of $(x+1)$. Means from 3 replications. 
Table 3 Shoot dry matter (SDM), root dry matter (RDM), SDM/RDM ratio and nitrogen accumulated in the shoot dry matter ( $\mathrm{N}_{\text {ac }}$ SDM) of cassava plantlets (Manihot esculenta Crantz) cv. (BRS Poti Branca e BRA Pretinha III) assessed for inoculation with of the plant growth promoting bacteria (PGPB)

\begin{tabular}{|c|c|c|c|c|c|c|c|c|}
\hline \multirow{4}{*}{ Tratamentos } & \multicolumn{8}{|c|}{ Cultivars } \\
\hline & $\begin{array}{l}\text { Poti } \\
\text { Branca }\end{array}$ & $\begin{array}{l}\text { Pretinha } \\
\text { III }\end{array}$ & $\begin{array}{l}\text { Poti } \\
\text { Branca }\end{array}$ & $\begin{array}{l}\text { Pretinha } \\
\text { III }\end{array}$ & $\begin{array}{l}\text { Poti } \\
\text { Branca }\end{array}$ & $\begin{array}{l}\text { Pretinha } \\
\text { III }\end{array}$ & $\begin{array}{l}\text { Poti } \\
\text { Branca }\end{array}$ & $\begin{array}{l}\text { Pretinha } \\
\text { III }\end{array}$ \\
\hline & SDM & & RDM & & SDM/RDN & & $\mathbf{N}_{\mathrm{ac}} \mathbf{S D M}$ & \\
\hline & $\mathbf{g}$ & & & & $g \cdot g^{-1}$ & & mg N planta-' & \\
\hline IG. diazotrophicus & $\begin{array}{l}0.37 \pm \\
0.03 \mathrm{aA}\end{array}$ & $\begin{array}{l}0.28 \pm \\
0.03 \mathrm{aB}\end{array}$ & $\begin{array}{l}0.15 \pm \\
0.01 \mathrm{aA}\end{array}$ & $\begin{array}{l}0.12 \pm \\
0.02 \mathrm{abcA}\end{array}$ & $\begin{array}{l}2.56 \pm \\
0.38 \mathrm{aA}\end{array}$ & $\begin{array}{l}2.70 \pm \\
0.24 \mathrm{abA}\end{array}$ & $\begin{array}{l}13.42 \pm \\
0.33 \mathrm{aA}\end{array}$ & $\begin{array}{l}12.05 \pm \\
1.63 \mathrm{aA}\end{array}$ \\
\hline Streptomyces sp & $\begin{array}{l}0.30 \pm \\
0.02 \mathrm{abA}\end{array}$ & $\begin{array}{l}0.30 \pm \\
0.02 \mathrm{aA}\end{array}$ & $\begin{array}{l}0.1 I \pm \\
0.01 \mathrm{abA}\end{array}$ & $\begin{array}{l}0.13 \pm \\
0.01 \mathrm{abA}\end{array}$ & $\begin{array}{l}2.85 \pm \\
0.1 \mathrm{IaA}\end{array}$ & $\begin{array}{l}2.4 I \pm \\
0.23 \mathrm{bA}\end{array}$ & $\begin{array}{l}\text { II.57士 } \\
\text { I.I0abA }\end{array}$ & $\begin{array}{l}11.01 \pm \\
0.67 \mathrm{abA}\end{array}$ \\
\hline $2 \mathrm{H}$. seropedicae & $\begin{array}{l}0.24 \pm \\
0.02 \mathrm{bcA}\end{array}$ & $\begin{array}{l}0.29 \pm \\
0.03 \mathrm{aA}\end{array}$ & $\begin{array}{l}0.09 \pm \\
0.02 \mathrm{abA}\end{array}$ & $\begin{array}{l}0.10 \pm \\
0.01 \mathrm{abcA}\end{array}$ & $\begin{array}{l}2.73 \pm \\
0.13 \mathrm{aA}\end{array}$ & $\begin{array}{l}2.84 \pm \\
0.20 \mathrm{abA}\end{array}$ & $\begin{array}{l}10.64 \pm \\
0.38 \mathrm{abA}\end{array}$ & $\begin{array}{l}12.25 \pm \\
1.24 \mathrm{aA}\end{array}$ \\
\hline 3A. amazonense & $\begin{array}{l}0.25 \pm \\
0.02 \mathrm{bcA}\end{array}$ & $\begin{array}{l}0.20 \pm \\
0.02 \mathrm{bcA}\end{array}$ & $\begin{array}{l}0.08 \pm \\
0.0 \mathrm{labA}\end{array}$ & $\begin{array}{l}0.06 \pm \\
0.01 \mathrm{abcA}\end{array}$ & $\begin{array}{l}3.37 \pm \\
0.22 \mathrm{aA}\end{array}$ & $\begin{array}{l}3.63 \pm \\
0.20 \mathrm{abA}\end{array}$ & $\begin{array}{l}\text { II. } .44 \pm \\
\text { I.24abA }\end{array}$ & $\begin{array}{l}8.27 \pm \\
0.88 \mathrm{abcB}\end{array}$ \\
\hline 4P. durus & $\begin{array}{l}0.17 \pm \\
0.02 c A\end{array}$ & $\begin{array}{l}0.16 \pm \\
0.02 \mathrm{bcA}\end{array}$ & $\begin{array}{l}0.05 \pm \\
0.01 \mathrm{bA}\end{array}$ & $\begin{array}{l}0.05 \pm \\
0.01 \mathrm{bcA}\end{array}$ & $\begin{array}{l}3.68 \pm \\
0.22 \mathrm{aA}\end{array}$ & $\begin{array}{l}4.23 \pm \\
0.93 \mathrm{abA}\end{array}$ & $\begin{array}{l}7.52 \pm \\
0.78 \mathrm{bcA}\end{array}$ & $\begin{array}{l}7.36 \pm \\
0.68 \text { bcdA }\end{array}$ \\
\hline P. graminis & $\begin{array}{l}0.19 \pm \\
0.02 c A\end{array}$ & $\begin{array}{l}0.13 \pm \\
0.01 \mathrm{cB}\end{array}$ & $\begin{array}{l}0.07 \pm \\
0.01 \mathrm{abA}\end{array}$ & $\begin{array}{l}0.03 \pm \\
0.01 \mathrm{cA}\end{array}$ & $\begin{array}{l}3.54 \pm \\
0.52 \mathrm{aA}\end{array}$ & $\begin{array}{l}4.93 \pm \\
0.98 \mathrm{aA}\end{array}$ & $\begin{array}{l}9.29 \pm \\
1.16 \mathrm{abcA}\end{array}$ & $\begin{array}{l}6.03 \pm \\
0.57 \mathrm{cdB}\end{array}$ \\
\hline P. brasiliensis & $\begin{array}{l}0.18 \pm \\
0.03 \mathrm{cB}\end{array}$ & $\begin{array}{l}0.26 \pm \\
0.02 \mathrm{abA}\end{array}$ & $\begin{array}{l}0.10 \pm \\
0.01 \mathrm{abA}\end{array}$ & $\begin{array}{l}0.15 \pm \\
0.08 \mathrm{aA}\end{array}$ & $\begin{array}{l}2.83 \pm \\
0.53 \mathrm{aA}\end{array}$ & $\begin{array}{l}4.18 \pm \\
1.38 \mathrm{abA}\end{array}$ & $\begin{array}{l}8.26 \pm \\
0.72 b c A\end{array}$ & $\begin{array}{l}\mid 1.51 \pm \\
0.49 \mathrm{abA}\end{array}$ \\
\hline CT & $\begin{array}{l}0.16 \pm \\
0.02 c A\end{array}$ & $\begin{array}{l}0.10 \pm \\
0.01 \mathrm{cA}\end{array}$ & $\begin{array}{l}0.05 \pm \\
0.0 \mathrm{lbA}\end{array}$ & $\begin{array}{l}0.03 \pm \\
0.00 c A\end{array}$ & $\begin{array}{l}3.73 \pm \\
0.46 a A\end{array}$ & $\begin{array}{l}3.46 \pm \\
0.11 \text { abA }\end{array}$ & $\begin{array}{l}6.26 \pm \\
0.86 \mathrm{cA}\end{array}$ & $\begin{array}{l}3.88 \pm \\
0.22 \mathrm{dA}\end{array}$ \\
\hline Means & 0.24 & 0.21 & 0.87 & 0.85 & 3.16 & 3.55 & 9.8 & 9.04 \\
\hline$\% C V$ & 31.43 & & 2.89 & & 16.52 & & 16.65 & \\
\hline
\end{tabular}

Means followed by the same lowercase letter between treatments within the same column and capital letter between varieties within the same row for each parameter do not differ at the Tukey test $(\mathrm{p}<0.05)$.' (Gluconacetobacter-BR I I 284); ${ }^{2}$ (Herbaspirillum-BR II I 75); ${ }^{3}$ (Azospirillum-BR I I I40); ${ }^{4}($ Paenibacillus: durus - V 2232, graminis-MC 04.21, brasiliensis - 24); Streptomyces S 30 and CT (control treatment). SDM (shoot dry matter); RDM (root dry matter). For statistical analysis the data on RDM and SDM/RDM were transformed into root of $(x+1)$. Means of 3 repetitions.

\section{Conclusion}

The scanning electron microscopy analysis revealed satisfactory colonization of the roots of the plants, excluding the plants that were inoculated with bacteria of the genus Paenibacillus, which showed a very low level of colonization. The strains of plant growth-promoting bacteria (PGPBs) that were used, although not homologous, optimized the plant height, stem diameter, dry mass of the shoot, dry mass of the root and accumulated nitrogen, which could result in the greater tolerance of plants to abiotic stresses caused by their transfer from an in vitro to an ex vitro environment. The cultivar "BRS Poti Branca" showed greater interactions with strain Glucanoacetobacter diazotrophicus, while the cultivar "BRA Pretinha III" had greater interactions with strains G. diazotrophicus, Streptomyces sp., $H$. seropedicae and Paenibacillus brasiliensis. The PGPBs resulted in the better performance of the cultivar "BRA Pretinha III" in relation to "BRS Poti Branca".

\section{Acknowledgements}

The authors are grateful to the National Council for Scientific and Tecnological Development (CNPq), Brasil and University Federal Rural de Pernambuco (UFRPE), University Estadual de Alagoas (UNEAL) and Agronomical Institute of Pernambuco (IPA), Brazil for financial support to research.

\section{Conflict of interest}

The author declares no conflict of interest.

\section{References}

1. FAO food and agriculture organization of the United Nations. Agricultural production, USA; 2014.

2. Okigbo BN. Nutritional implications of projects giving high priority to the production of staples of low nutritive quality. In the case for cassava (Manihot esculenta Crantz) in the humid tropics of West Africa. Food and Nutrition Bulletin. 1980;2(4):1-10. 
3. Olukunle OT. Evaluation of income and employment generation from cassava value chain in the Nigerian agricultural sector. Asian Journal of Agriculture and Rural Development. 2013;3:79-92.

4. El-Sharkawy MA. Stress-tolerant cassava: The role of integrative ecophysiology-breeding research in crop improvement. Open Journal of Soil Science. 2012;2:162-186.

5. Iglesias C. Memorias de la Tercera Reunion Panamericana de Fitomejoradores de Yuca. Documento de Trabajo \# 138. CIAT, Cali, Colombia; 1994. p. $1-11$

6. Mattos PLP, Souza AS, Filho JRF. Propagação. In: Souza, editors. Aspectos socioeconômicos e agronômicos da mandioca. Cruz das Almas:Embrapa Mandioca e Fruticultura Tropical; 2006. p. 70-214.

7. Pasqual M, Soares JDR, Rodrigues FA. Tissue culture applications for the genetic improvement of plants. In: BORÉM, A.; Fritsche-Neto, R. Biotechnology and Plant Breeding: Applications and Approaches for Developing Improved Cultivars cap. 2014;7:157-178.

8. Mello MRF, Mariano RLR, Menezes M, et al. Seleção de bactérias e métodos de bacterização para promoção de crescimento em mudas de abacaxizeiro micropropagadas. Summa Phytopathol. 2002;34(2):222-228.

9. Kapoor R, Sharma D, Bhatnagar AK. Arbuscular mycorrhizae in micropropagation systems and their potential applications. Sci Hort. 2008;116(3):227-239.

10. Panicker B, Thomas P, Janakiram T, et al. Influence of cytokinin levels on in vitro propagation of shy suckering chrysanthemum "Arka Swarna" and activation of endophytic bacteria. In vitro Cellular and Developmental Biology-Plant. 2007;43(6):614-622.

11. Pablo Bogino, Ayelén Abod, Fiorela Nievas, et al. Water-Limiting Conditions Alter the Structure and Biofilm-Forming Ability of Bacterial Multispecies Communities in the Alfalfa Rhizosphere. PLOS ONE. 2013;8:e79614.

12. Figueiredo MVB, Araújo ASF, Burity HA, et al. Biodiversity and potential of PGPR: plant microorganism interactions In:Microbial Ecology of Tropical Soil ed. USA: Nova Science Publishers; 2010;1:127-156.

13. Chanway CP, Anand R, Yang H. Nitrogen fixation outside and inside plant tissues, advances in biology and ecology of nitrogen fixation, advances in biology and ecology of nitrogen fixation; 2014.

14. Brian M Hoffman, Dmitriy Lukoyanov, Zhi-Yong Yang, et al. Mechanism of Nitrogen Fixation by Nitrogenase: The Next Stage. C Chem Rev. 2014;114(8):4041-4062.

15. Richardson AE, Simpson RJ. Soil microorganisms mediating phosphorus availability update on microbial phosphorus. Plant Physiology. 2011;156(3):989-996.

16. Sarathambal C, Thangaraju M, Paulraj C, et al. Assessing the Zinc solubilization ability of Gluconacetobacter diazotrophicus in maize rhizosphere using labelled 65Zn compounds. Indian Journal of Microbiology. 2010;50(1):103-109.

17. El-Tarabily KA, Soaud AA, Saleh ME, et al. Isolation and characterization of sulfur-oxidising bacteria, including strains of Rhizobium, from calcareous sandy soils and their effects on nutrient uptake and growth of maize (Zea mays L.). Australian Journal of Agricultural Research. 2006;57:101-111.

18. Malfanova N, Kamilova F, Validov S, et al. Characterization of Bacillus subtilis HC8, a novel plant-beneficial endophytic strain from giant hogweed. Microb Biotechnol. 2011;4(4):523-532.

19. Kurepin LV, Zaman M, Pharis RP. Phytohormonal basis for the plant growth promoting action of naturally occurring biostimulators. $J \mathrm{Sci}$ Food Agric. 2014;94(9):1715-1722.
20. Bashan Y, De-Bashan LE. How the plant growth-promoting bacterium Azospirillum promotes plant growth-a critical assessment. Advances in Agronomy. 2010;108:77-136.

21. Fabricio Cassán, Jos Vanderleyden, Stijn Spaepen. Physiological and agronomical aspects of phytormone production by model plant-growthpromoting rhizobacteria (PGPR) belonging to the genus Azospirillum. Journal of Plant Growth Regulation. 2014;33(2):440-459.

22. Figueiredo MVB, Burity HA, Martinez CR, et al. Alleviation of water stress effects in cammom bean (Phaseolus vulgaris L.) by co-inoculation Paenibacillus x Rhizobium tropici. Applied Soil Ecology. 2008;40:182188

23. Carvalhais LC, Dennis PG, Fan B, et al. Linking plant nutritional status to plant-microbe interactions. PLOS One. 2013;8(7):e68555.

24. Araújo WL, Marcon J, Maccheroni W, et al. Diversity of endophytic bacterial populations and their interations with Xylella fastidiosa in citrus plants. Appl Environ Microbiol. 2002;68(10):4906-4914.

25. Souza A da S, Junghans TG, Souza FVD, et al. Micropropagação da mandioca. In: JUNGHANS TG, editor. Aspectos práticos da micropropagação de plantas. Cruz das Almas:Embrapa Mandioca e Fruticultura Tropical, Brazil; 2009. p. 323-349.

26. Murashige T, Skoog F. A revised medium for rapid growth and bio-assays with tobacco tissue culture. Physiol Plan. 1962;15:473-497.

27. Roca WM, Nolt B, Mafla G, et al. Eliminación de virus y propagación de clones en la yuca (Manihot esculenta Crantz). In: Roca, WM \& Mroginski LA Fundamentos y aplicaciones; 1991. p. 403-421.

28. Reis VM. Método de inoculação de bactérias diazotróficas em plantas de cana-de-açúcar micropropagadas. Comunidade Técnico Embrapa Agrobiologia; 2004. 65 p.

29. EMBRAPA Empresa Brasileira de Pesquisa Agropecuária. Centro Nacional de Pesquisa de Solos. Sistema Brasileiro de Classificação de Solos. Brasília: Embrapa Produção de informação, Rio de Janeiro: Embrapa Solos, 3rd ed. 2013. p. 1-353

30. Hoagland DR, Arnon DI. The water culture method for growing plants without soils. Berkeley: California Agricultural Experimental Station, USA; 1950. p. 1-347.

31. Silveira JAG, Contado JL, Mazza JLM, et al. Phosphoenolpyruvate carboxylase and glutamine synthetase activities in relation to nitrogen fixation in cowpea nodules. R Bras Fisiol Veget. 1998;10:9-23.

32. Bashan Y, De-Bashan LE. Bacteria. In: Encyclopedia of Soils in the Environment. 2005;1:103-115.

33. Pillay VK, Nowak J. Inoculum density, temperature, and genotype effects on in vitro growth promotion and epiphytic and endophytic colonization of tomato (Lycopersicon esculentum L.) seedlings inoculated with a pseudomonad bacterium. Can J Microbiol. 1997;43(4):354-361.

34. Kuklinsky-Sobral J, Araújo WL, Mendes R, et al. Isolation and characterization of soybean-associated bacteria and their potential for plant growth promotion. Environ Microbiol. 2004;6(12):244-1251.

35. Fromin N, Achouak W, Thiery JM, et al. The genotypic diversity of Pseudomonas brassicacearum populations isolated from roots of Arabidopsis thaliana:influence of plant genotype. FEMS Microbiol Ecol. 2001;37(1):21-29.

36. Figueiredo MVB, Sobral JK, Stamford TLM, et al. Bactérias promotoras do crescimento de plantas: estratégia para uma agricultura sustentável In: Figueiredo MVB, editor. Biotecnologia aplicada à agricultura: textos de apoio e protocolos experimentais. Brasília: Brazilian Agricultural Research Corporation, Brazili; 2010;1:387-414. 
37. Mathur A, Mathur AK, Verma P. Biological hardening and genetic fidelity testing of micro-cloned progeny of Chlorophytum borivilianum. Afr J Biotechnol. 2008;7(8):1046-1053.

38. Santos JA, Silva CRR, Carvalho JG, et al. Efeito do calcário dolomítico enitrato de potássio no desenvolvimento inicial de mudas da bananeira 'Prata-Anã' (AAB), provenientes de cultura in vitro. Rev Bras Fruticultura. 2004;26(1):150-154.

39. Naik BS, Shashikala J, Krishnamurthy YL. Host growth characteristics influenced by seed inoculation with microorganisms. WJAS. 2008;4:891895.

40. Probanza A, Lucas JA, Acero N, et al. The influence of native rhizobacteria on European alder (Alnus glutinosa (L.) Gaertn.) growth. 1. Characterization of growth promoting and growth inhibiting bacterial strains Plant and Soil. 1996;182(1):59-66.

41. Saharan BS, Nehra V. Plant Growth promoting rhizobacteria: 2011. A critical review. Life Sciences and Medicine Research. 2011;21(1):1-30.

42. Valé M, Nguyen C, Dambrine E, et al. Microbial activity in the rhizosphere soil of six herbaceous species cultivated in a greenhouse is correlated with shoot biomass and root C concentrations. Soil Bio. 2005;37(12):2329-2333.

43. Araújo FF. Rizobactérias e indução de resistência a doenças em plantas. Part II-Micro-organismos Promotores de Crescimento em Plantas. In Figueiredo M editor. Micro-organismos e agrobiodiversidade: o novo desafio para agricultura. Guaíba Agrolivros; 2008. p. 197-210.

44. Alves AAC. Fisiologia da mandioca. In: Souza L, et al. editors. Aspectos socioeconômicos e agronômicos da mandioca. Embrapa Mandioca e Fruticultura Tropical, Cruz das Almas, Brazil; 2006. p. 1-2.

45. Canuto EL, Salles JF, Oliveira ALM, et al. Resposta de plantas micropropagadas de cana-de-açúcar à inoculação de bactérias diazotróficas endofíticas. Agronomia. 2003;37:67-72.

46. Aguilar-Piedras JJ, Xiqui-Vasquez ML, Garcia-Garcia S, et al. Indole-acetic acid production in Azospirillum. Rev Latinoam Microbio. 2008;50:29-37.

47. Meguro AY, Ohmura Y, Hasegawa S, et al. An endophytic actinomycete, Streptomyces sp. MBR-52, that accelerates emergence and elongation of plant adventitious roots. Actinomycetologica. 2006;20(1):1-9.

48. Rodrigues AC, Antunes JEL, Costa AF, et al. Interrelationship of bradyrhizobium sp. and plant growth-promoting bacteria in cowpea:survival and symbiotic performan. J Microbiol. 2013;51(1):49-55.

49. Bashan Y, Levanony H. Current status of Azospirillum inoculation technology:Azospirillum as a challenge for agriculture. Can J Microbiol. 1990;36(9):591-608
50. de-Bashan LE, Hernandez JP, Bashan Y. The potential contribution of plant growth-promoting bacteria to reduce environmental degradation-A comprehensive evaluation. Appl Soil Ecol. 2012;61:171-189.

51. Aldesuquy HS, Mansour FA, Abo-Hamed SA. Effect of the culture filtrates of Streptomyces on growth and productivity of wheat plants. Folia Microbiologica. 1998;43(5):465-470.

52. Baldani JI, Baldani VLD, Seldin L, et al. Characterization of Herbaspirillum seropedicae gen. nov., sp. nov., a root-associated nitrogen fixing bacterium. Int J Syst Bacteriol. 1986;36(1):86-93.

53. Banik S, Dey BK. Available phosphate content of an alluvial soil as influenced by inoculation of some isolated phosphate solubilizing microorganisms. Plant Soil. 1982;69(3):353-364.

54. Bastián F, Cohen A, Piccoli P, et al. Production of indole-3-acetic acid and gibberellins A1 and A3 by Acetobacter diazotrophicus and Herbaspirillum seropedicae in chemically defined culture media. Plant Growth Regulation. 1998;24(1):7-11.

55. Dobbelaere S, Vanderleyden J, Okon Y. Plant growth-promoting effects of diazotrophs in the rhizosphere. Critical Reviews in Plant Sciences. 2003;22(2):107-149.

56. Gopalakrishnan S, Srinivas V, Alekhya G, et al. The extent of grain yield and plant groth enhancement by plant groth-promoting broad-spectrum Streptomyces sp. In chickpea. Springer Plus. 2015;4:1-31.

57. Madhaiyan M, Saravanan VS, Bhakiya Silba Sandal Jovi D, et al. Occurrence of Gluconacetobacter diazotrophicus in tropical and subtropical plants of Western Ghats. India Microbiol Res. 2004;159(8):233-224.

58. Rodrigues EP, Rodrigues LS, de Oliveira ALM, et al. Azospirillum amazonense inoculation:effects on growth, yield and N2 fixation of rice (Oryza sativa L.). Plant and soil. 2008;302(1-2):249-261.

59. Sevilla M, Burris RH, Gunapala N, et al. COMPARISON of benefit to sugarcane plant growth and $15 \mathrm{~N} 2$ incorporation following inoculation of sterile plants with Acetobacter diazotrophicus wild type and Nif-mutant strains. Mol Plant-Microbe Interact. 2010;14(3):358-366.

60. Tokala RK, Strap JL, Jung CM, et al. Novel plant-microbe rhizosphere interaction involving Streptomyces lydicus WYEC108 and the pea plant (Pisum sativum). Appl Environ Microb. 2002;68(5):2161-2171.

61. Weller DM. Pseudomonas Biocontrol agents of soilborne pathogens:Looking back over 30 years. Phytopathology. 2007;97(2):250-256.

62. Seldin L. Paenibacillus fixadores de nitrog nio:part II:microrganismos promotores de crescimento em plantas. In: Figueiredo M, do VB, Burity HA, Stamford, NP \& Santos, CERS. Microrganismos e agrobiodiversidade: o novo desafio para agricultura. Guaíba:Agrolivros. 2008;1:259276 